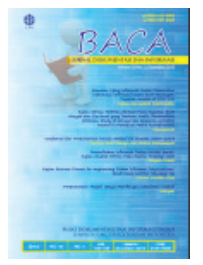

\title{
STRATEGI MEMPROMOSIKAN INFORMASI HASIL PENELITIAN: STUDI PADA PUSAT DOKUMENTASI DAN INFORMASI ILMIAH LEMBAGA ILMU PENGETAHUAN INDONESIA
}

\author{
Yati Suryati*1, Eduard Lukman ${ }^{2}$ \\ ${ }^{1,2}$ Fakultas Ilmu Sosial dan Ilmu Politik - Universitas Indonesia \\ ${ }^{1}$ Pusat Dokumentasi dan Informasi Ilmiah - LIPI \\ *Korespondensi: halwa_adzkia@yahoo.com
}

Diajukan: 26 Juli 2017; Direview: 29 Agustus 2017; Diterima: 10 September 2017; Direvisi: 18 Oktober 2017

\begin{abstract}
Center for Scientific Documentation and Information of Indonesian Institute of Sciences has already created a platform system which is intended to facilitate people in accessing and obtaining the scientific information. The institution promotes platform services which enable people to easily find the scientific information required for their research paper. This study aims at analyzing the corporate promotional communication strategies. Researchers use eight effective promotional communication elements which consist of identifying the targeted audience, determining the communication objectives, designing the messages, selecting the channels, budgeting, deciding promotional tools, measuring the results, managing and coordinating the integrated marketing communications. This research is a single case study which data are collected from in-depth interviews, and documentation studies. The results show that the promotional communication strategies have already fulfilled seven of eight effective promotion communication elements although it is still not optimal yet. The element which has not been fulfilled is on measuring the promotional results. Cost budgeting is one element which also requires to be optimized more. It would be better if the institution uses objective and task method to clearly define the specific objectives and determine the required tasks to perform in achieving those objectives as well as to estimate costs in performing those tasks. By implementing these methods, it is expected that the short-term and long-term goals may be clearly defined that the goals of the promotional activities may be achieved better. In addition, the team formation focusing on the promotional activities may also become a consideration for the effectively and efficiently integrated marketing and promotional communication.
\end{abstract}

\begin{abstract}
ABSTRAK
Pusat Dokumentasi dan Informasi Ilmiah Lembaga Ilmu Pengetahuan Indonesia mempunyai produk dan layanan akses informasi hasil penelitian untuk memudahkan masyarakat memperoleh informasi ilmiah hasil penelitian dan mempromosikannya agar masyarakat mengetahui dan memanfaatkannya. Penelitian ini bertujuan untuk menganalisis program promosi lembaga. Peneliti menggunakan delapan unsur komunikasi promosi efektif dari Kotler yang terdiri dari penentuan target sasaran, penentuan tujuan komunikasi, perancangan pesan komunikasi, penentuan saluran komunikasi, penentuan anggaran biaya, penentuan bauran promosi, pengukuran hasil promosi dan pengelolaan serta pengkoordinasian komunikasi pemasaran terpadu. Penelitian merupakan studi deskriptif dengan desain studi kasus single level analysis. Pengumpulan data dilakukan dengan wawancara mendalam dan studi dokumen. Hasil penelitian menunjukkan bahwa strategi komunikasi promosi yang dilakukan oleh lembaga telah memenuhi tujuh komponen dalam komunikasi promosi yang efektif walaupun belum optimal. Komponen yang belum terpenuhi adalah pengukuran hasil promosi. Komponen yang harus lebih dioptimalkan lagi adalah bagian penganggaran biaya. Akan lebih baik apabila lembaga menggunakan metode tujuan dan tugas dalam pembiayaanya dibandingkan dengan metode sesuai kemampuan. Pada metode tujuan dan tugas, tujuan spesifik mengenai apa yang ingin dicapai dalam kegiatan promosi dapat dirumuskan dengan jelas diikuti oleh tugas atau pekerjaan apa yang harus dilakukan untuk memenuhi tujuan tersebut. Pembiayaan didasarkan pada tugas-tugas yang harus dilakukan. dengan metode ini,
\end{abstract}


tujuan jangka pendek dan jangka panjang dari suatu kegiatan promosi dapat dicapai dengan lebih baik. Selain itu, pembentukan tim promosi yang khusus dan fokus pada kegiatan promosi juga harus menjadi pertimbangan lembaga agar komunikasi promosi dan pemasaran terpadu dapat berjalan dengan efektif dan efisien.

Keywords: Communication strategy; Promotion; Research information; Marketing communication; Scientific information

\section{PENDAHULUAN}

Para peneliti dan akademisi membutuhkan publikasi ilmiah dalam bentuk jurnal ilmiah sebagai media aktualisasi dalam pengembangan ilmu pengetahuan, terutama jurnal ilmiah bereputasi internasional. Publikasi ilmiah dengan reputasi internasional dapat meningkatkan harga diri bangsa melalui diplomasi ilmu pengetahuan dan mutu pendidikan.Sebuah jurnal ilmiah umumnya memuat berbagai artikel dari hasil penelitian yang telah dilakukan. Dengan terbitnya artikel ilmiah, hasil penelitian yang sudah dilakukan dapat diakses dan dijadikan rujukan oleh masyarakat. Selain itu, peneliti bisa mengikuti tren perkembangan ilmu pengetahuan dan teknologi di bidangnya melalui jurnal ilmiah. Namun, akses terhadap literatur ilmiah ini mempunyai keterbatasan. Tidak semua perpustakaan ataupun pusat dokumentasi berlangganan jurnal ilmiah yang cukup lengkap untuk memenuhi kebutuhan peneliti maupun akademisi. Keberadaan sebuah platform system yang dapat memberi akses pada informasi ilmiah bisa menjadi solusi untuk membantu peneliti dan akademisi menemukan sumber informasi ilmiah yang dibutuhkannya.

Di Indonesia saat ini terdapat lebih dari 7000 jurnal ilmiah yang diterbitkan. Untuk dapat mengakses jurnal-jurnal tersebut, pembaca diharuskan menghubungi redaksi jurnal atau mencari di perpustakaan lembaga tempat jurnal tersebut diterbitkan. Hal ini yang mendasari Pusat Dokumentasi dan Informasi Ilmiah (PDII-LIPI) untuk membuat sebuah platform layanan untuk mengakses jurnal ilmiah yang memudahkan para pengguna, namun tetap mengedepankan kualitas. Layanan tersebut diberi nama Indonesian Scientific Journal Database (ISJD). .Dalam laman ISJD, pengguna dapat mendaftarkan diri menjadi member dan mengakses ratusan ribu artikel dari ribuan jurnal yang tersedia dengan sangat mudah. Selain memberikan kemudahan akses bagi penggunanya, ISJD juga memuat artikel jurnal yang ada dalam jurnal cetak sehingga perkembangan jurnal ilmiah, baik cetak maupun elektronik, dapat terlihat dalam laman ISJD. Selain itu, PDII juga menyediakan tempat bagi masyarakat yang memerlukan informasi ilmiah berupa buku, laporan hasil penelitian, tesis, disertasi, serta artikel jurnal ilmiah dalam bentuk hardcopy. Untuk memenuhi kebutuhan pengguna yang ingin mengakses informasi melalui internet, PDII juga menyediakan sistem informasi yang diberi nama Library and Archive System (LARAS). Sampai dengan Desember 2016, ISJD memuat 299.426 artikel jurnal yang berasal dari 7.526 jurnal ilmiah.Sementara itu, LARAS memuat 75.916 makalah ilmiah yang berasal dari prosiding konferensi ilmiah, 77.426 laporan penelitian, 88.034 buku, 32.896 tesis/disertasi, dan 6.859 paten. Di bulan Agustus 2015, PDII meluncurkan versi terbaru dari ISJD, yaitu Neo ISJD. Pada versi terbaru ini, pengguna dapat mendaftaran diri sebagai member dan langsung dapat mengunduh artikel di dalamnya secara gratis.

Data BPS tahun 2015 menunjukkan komposisi mahasiswa, dosen, dan peneliti di Indonesia sebanyak 5.913.252 mahasiswa perguruan tinggi negeri dan swasta, 257.606 dosen, serta 9.308 peneliti. Jumlah tersebut belum ditambah dengan jumlah guru dan siswa yang pastinya membutuhkan informasi ilmiah untuk pengayaan bahan ajar di sekolah. Jumlah ini 
merupakan captive market yang sangat besar dan menjadi pengguna potensial untuk ISJD, LARAS, maupun layanan informasi ilmiah lain yang disediakan oleh PDII. Agar informasi ilmiah hasil penelitian tersebut dapat dikenal serta diakses oleh masyarakat luas, PDII melakukan kegiatan promosi untuk dapat menyosialisasikan produk layanan akses informasi yang telah dibuat.

Promosi yang dilakukan PDII biasanya berupa keikutsertaan dalam pameran-pameran yang diselenggarakan, baik oleh LIPI maupun undangan dari instansi lain. Di ajang pameran itulah PDII banyak mempromosikan mengenai produk dan jasanya, terutama mengenai ISJD.Tim pameran umumnya menyiapkan satu buah komputer yang dapat digunakan oleh pengunjung pameran untuk mencoba fitur dan konten yang ada di ISJD. Namun, walau promosi sudah dilakukan, pengguna layanan atau pengakses ISJD dari tahun ke tahun menunjukkan penurunan. Pada tahun 2013, pengguna ISJD mencapai angka 511.074 orang dalam satu tahun, pada tahun 2014 menurun menjadi 399.149 pengguna, tahun 2015 menurun lagi menjadi 270.245 pengguna, dan di tahun 2016 ini sampai dengan tanggal 6 desember 2016, jumlah pengguna ISJD mencapai 227.541 orang.

Membahas promosi dan pemasaran dari berbagai literatur, ada banyak yang menyatakan bahwa konsep pangsa pasar (market share) merupakan fungsi dari empat komponen besar, yaitu awareness, product attractiveness, no price barrier, dan availability. Keempat komponen ini dapat menjadi dasar bahwa suatu produk akan dibeli atau digunakan oleh konsumennya kemudian produk tersebut akan memperoleh pangsa pasarnya. Brand awareness mempunyai arti tingkat pengetahuan seseorang terhadap sebuah merek dari suatu produk. 'brandawareness $i$ s the ability of a potential buyer to recognize or recall that a brand is a member of certain product category' (Aaker, 1991). Terdapat empat tingkat dari brand awareness, yaitu unaware brand, brand recognition, brand recall (pengingatan kembali merek), dan top of mind (puncak pikiran) yang merupakan level tertinggi dari brand awareness. Pada level ini, merek suatu produk akan langsung diingat pertama kali secara spontan oleh pengguna ketika akan menggunakan produk pada kategori yang sama. Semakin tinggi level brand awareness dari suatu produk, maka itu berarti merek produk tersebut semakin dekat dengan konsumen bahkan sudah tertanam dalam benak konsumen dibandingkan dengan merek lain dari produk yang serupa. Kemudian, brand awareness itu bukan saja saja sebagai daya ingat, tetapi menjadi suatu proses pembelajaran bagi konsumen terhadap suatu merek produk.

Penentuan target audiens merupakan salah satu komponen penting dalam promosi. Hal ini dapat ditemukan melalui proses segmenting, targeting, dan positioning dari suatu produk. Dalam mempromosikan produk dan layanannya, PDII menyasar komunitas ilmiah seperti mahasiswa, dosen, peneliti, dan pustakawan sebagai target audiensnya. Kembali pada komposisi jumlah mahasiswa, dosen, dan peneliti yang menjadi pengguna potensial dari produk informasi hasil penelitian yang dibuat oleh PDII, dengan jumlah yang besar itu seharusnya layanan akses informasi hasil penelitian dapat terus menjadi rujukan referensi untuk artikel jurnal ilmiah. Selain itu, bisa menjadi top of mind untuk produk layanan informasi hasil penelitian. Alasannya, setiap orang yang akan memuat sebuah karya tulis ilmiah pastilah membutuhkan sejumlah referensi ilmiah yang berkualitas dan terpercaya.

Saat ini, penyedia layanan informasi ilmiah seperti ISJD mulai bermunculan. Sebut saja Portal Garuda yang diluncurkan oleh Kementerian Pendidikan Nasional pada tahun 2010, dan Indonesian Publication Index (IPI) yang mulai muncul pada tahun 2012. Untuk bisa menjadi top of mind dan memenangkan persaingan pada jasa penyedia layanan informasi 
ilmiah, PDII harus melakukan upaya promosi yang efektif. Penelitian ini bertujuan untuk menganalisis strategi komunikasi promosi yang digunakan oleh PDII dalam mempromosikan produk dan layanan akses informasi hasil penelitian agar masyarakat dapat memanfaatkannya secara optimal.

\section{TINJAUAN LITERATUR}

Kegiatan promosi suatu lembaga sering kali didefinisikan sebagai kegiatan komunikasi persuasif yang dilakukan untuk mendapatkan kepastian bahwa khalayak sasaran dapat memahami penawaran yang diajukan serta memercayai bahwa mereka akan memperoleh manfaat dari penawaran tersebut kemudian terdorong untuk membeli atau menggunakan produk yang ditawarkan. Pengembangan komunikasi dalam suatu kegiatan promosi merupakan suatu proses yang bermula dari menentukan target sasaran, menentukan tujuan komunikasi, merancang pesan, memilih saluran komunikasi, menentukan anggaran, menentukan bauran promosi, mengukur hasil promosi, serta mengelola dan mengoordinasikan komunikasi pemasaran terpadu.

Tahap pertama adalah mengidentifikasi, siapakah pengguna produk atau layanan yang akan dipromosikan. Hal ini sangat penting mengingat target sasaran akan sangat menentukan kegiatan promosi yang akan dilakukan mulai dari kepada siapa pesan akan disampaikan, apa yang akan disampaikan, bagaimana cara penyampaiannya, kapan waktu yang tepat untuk disampaikan, dan di mana akan disampaikan. Proses pengidentifikasian ini dapat dilakukan dengan cara menentukan segmentasi, target, dan positioning produk atau layanan yang akan dipasarkan. Dengan melakukan segmentasi, organisasi dapat memenuhi kebutuhan pengguna dengan produk atau layanan yang dipasarkan. Membentuk suatu segmen pasar dapat dilakukan dengan berbagai cara, salah satunya dengan mengidentifikasi preferensi segmen.

Menurut Kotler (2000), terdapat tiga pola preferensi yang umumnya muncul, yaitu preferensi homogen, preferensi tersebar, dan preferensi terkelompok. Ada beberapa tahap yang bisa dilakukan untuk penentuan segmen ini seperti yang dinyatakan oleh Kotler (2000) proses segmentasi bisa dimulai dengan melakukan survei untuk mengetahui motivasi, sikap, dan perilaku dari konsumen. Setelah itu, hasil survei dianalisis dengan menggunakan analisis faktor yang dilanjutkan dengan analisis kluster untuk dapat menghasilkan jumlah segmen. Langkah terakhir adalah membuat profiling dari segmen yang telah terbentuk berdasarkan sikap, perilaku, demografis, psikografis, dan pola media. Setelah itu, segmen dapat diberi nama sesuai dengan sifat yang mendominasinya karena variabel utama yang membentuk segmentasi ada empat (Kotler 2000), yaitu geografis, demografis, psikografis, dan perilaku. Setelah segmen diketahui, langkah selanjutnya adalah menentukan target pengguna dengan cara menentukan segmen yang akan dimasuki dan menentukan segmen mana yang paling potensial. Proses ini disebut dengan targeting atau penentuan target. Kemudian, langkah terakhir adalah menentukan posisi produk atau disebut dengan positioning. Menurut David Aaker dan John Myers, positioning biasanya digunakan untuk menunjukkan citra merek dari suatu produk di pasaran karena positioning merupakan faktor kunci agar dapat mengomunikasikan manfaat produk dan membedakan produk dari para pesaingnya. Menurut Kotler dan Andreasen (1995), dalam konteks pemasaran sosial, ada lima kategori positioning yang dapat digunakan, yaitu: (1) positioning yang berfokus pada perilaku; (2) positioning yang fokus pada manfaat; (3) positioning yang fokus pada hambatan (menjadi solution problem pengguna); (4) positioning yang fokus pada reposisi; dan (5) positioning yang fokus pada posisi persaingan. 
Tahap kedua adalah menentukan tujuan dari komunikasi yang akan dilakukan. Penentuan tujuan ini berkaitan dengan tanggapan apa yang diinginkan oleh organisasi dari target sasaran yang telah diidentifikasi. Tanggapan dari target audience biasanya berupa tanggapan kognitif, afektif, atau psikomotorik. Hal ini berarti bahwa organisasi sebagai komunikator bermaksud untuk memasukkan pemahaman atau mempersuasi target sasaran untuk mengubah sikap atau mendorong target sasaran untuk bertindak. John R. Rossiter dan Larry Percy dalam Kotler \& Keller (2012) mengidentifikasi tujuan komunikasi menjadi empat, yaitu:

1) Membangkitkan keinginan akan suatu kategori produk (category need) dan menciptakan permintaan primer (primary demand) dari target sasarannya.

2) Menciptakan kesadaran merek (brand awareness). Dalam hal ini, komunikator harus berusaha untuk mengarahkan upaya komunikasinya pada penciptaan kesadaran merek serta berupaya untuk mempengaruhi sikap serta niat positif atas merek. Kesadaran akan merek membuat target sasaran menjadi familiar dengan merek dari produk yang dibuat karena mereka mengenali ciri khusus dari produk dan manfaatnya serta perbedaan produk dengan pesaingnya dari kategori yang sama.

3) Mendorong sikap positif terhadap produk serta mempengaruhi niat (brand attitude and intention). Komunikasi ditujukan untuk membentuk sikap positif terhadap merek dan memunculkan niat dari target sasaran untuk menggunakan produk itu sekarang ataupun di masa datang.

4) Memfasilitasi pembelian (brand purchase intention). Display produk yang menarik, iklan yang efektif, dan variabel komunikasi lainnya dapat berfungsi untuk memfasilitasi pembelian serta manjadi solusi bagi persoalan yang timbul dari variabel bauran pemasaran lain nonpromosi seperti variabel harga, produk, dan distribusi.

Tahap ketiga adalah merancang pesan komunikasi. Komunikator harus dapat merancang sebuah pesan yang benar-benar efektif. Dalam memformulasikan pesan, harus dipertimbangkan empat hal yang biasanya menjadi permasalahan, yaitu isi pesan (apa yang akan dikatakan), struktur pesan (bagaimana mengatakannya secara logis), format pesan (bagaimana mengatakannya secara simbolis), dan sumber pesan (siapa yang harus mengatakannya). Ketika menentukan isi pesan, komunikator harus dapat mencari daya tarik, tema, dan ide yang unik.Ada tiga jenis daya tarik yang bisa digunakan, yaitu daya tarik rasional yang dapat membangkitkan minat seseorang; daya tarik emosional yang mencoba membangkitkan emosi positif ataupun negatif yang akan memotivasi pembelian atau penggunaan produk; dan daya tarik moral yang diarahkan pada perasaan target sasaran mengenai sesuatu yang benar dan tepat. Selain itu, efektivitas pesan pun akan sangat bergantung pada isi dan struktur pesan.

Menurut Hovland dalam Kotler \& Keller (2012) terdapat tiga struktur pesan yang biasanya digunakan yaitu: (1) penyajian sepihak (one-sided presentation), yaitu komunikator menyampaikan berbagai keunggulan dari produk; (2) argumen dua pihak (two-sided argument) yaitu pesan disajikan dengan cara menunjukan kekurangan maupun keunggulan dari produk,; (3) urutan penyajian yang merupakan struktur penyajian pesan dengan memberi tekanan penguatan pada bagian-bagian tertentu yang ingin ditonjolkan. Selain struktur pesan, komunikator pun harus mengembangkan format pesan yang kuat. Apabila pesan komunikasi disampaikan dalam bentuk media tercetak, komunikator harus memastikan judul, kata-kata, ilustrasi, serta warna yang akan digunakan. Selain isi, struktur, dan format, sumber pesan pun menjadi salah satu faktor keberhasilan sebuah komunikasi. Sumber pesan yang menarik dan 
terkenal akan mudah mendapat perhatian serta pesan yang disampaikan akan lebih cepat diingat orang. Namun, kredibilitas sumber pesan merupakan hal utama yang harus menjadi pertimbangan.Terdapat tiga faktor yang melandasi kredibilitas sumber pesan, yaitu: (1) expertise atau keahlian; (2) trustworthiness atau kelayakan untuk dipercaya; dan (3) likeability atau kemampuan untuk disukai. Dari ketiga faktor tersebut, faktor trustworthiness merupakan faktor yang paling utama dan memiliki peringkat tertinggi dalam pemilihan sumber pesan.

Tahapan keempat, yaitu pemilihan saluran komunikasi. Komunikator harus dapat memilih saluran komunikasi yang efektif dan efisien untuk dapat menyampaikan pesan komunikasinya.Untuk hal tersebut, diperlukan berbagai macam saluran komunikasi yang berbeda yang dapat digunakan dalam berbagai konteks komunikasi. Secara umum, saluran komunikasi terbagi menjadi dua, yaitu saluran komunikasi personal dan saluran komunikasi nonpersonal atau massal.Saluran komunikasi personal biasanya melibatkan dua orang atau lebih yang berkomunikasi secara langsung. Cara komunikasi yang digunakan bisa berupa komunikasi tatap muka langsung, melalui telepon, surat elektronik atau bentuk komunikasi satu orang ke banyak orang, seperti ceramah. Efektivitas saluran komunikasi personal dapat diperoleh melalui individualisasi penyajian serta umpan balik yang didapat. Sementara itu, saluran komunikasi nonpersonal atau massal meliputi media dan acara khusus. Media yang digunakan sebagai saluran nonpersonal terdiri dari: (1) media cetak seperti koran dan majalah; (2) media penyiaran seperti radio dan televise; (3) media elektronik seperti videodisc, CDROM, dan website; dan (4) media pajangan seperti papan reklame, tanda reklame, dan poster. Sering kali saluran komunikasi personal dianggap lebih efektif dibandingkan dengan saluran nonpersonal, namun saluran nonpersonal bisa menjadi pintu utama untuk mendorong komunikasi personal.

Tahap kelima adalah penentuan anggaran biaya dan hal ini merupakan keputusan tersulit bagi organisasi untuk menentukan seberapa besar dana untuk promosi yang dapat dikeluarkan. Menurut Kotler (2000), ada empat metode utama yang dapat digunakan untuk menyusun anggaran promosi yaitu: (1) metode sesuai kemampuan (affordable method) dalam hal ini, organisasi menetapkan anggaran promosi berdasarkan kemampuannya; (2) metode persentase penjualan, metode ini menetapkan anggaran promosi berdasarkan presentasi tertentu dari penjualan atau harga jual; (3) metode keseimbangan persaingan (competitive parity method) metode ini digunakan organisasi untuk mencapai keseimbangan pangsa pasar suara promosi dengan para pesaingnya; (4) metode tujuan dan tugas (objective and task method) metode ini mengembangkan anggaran promosi dengan mendefinisikan tujuan spesifik dan menentukan tugas yang harus dilakukan untuk mencapai tujuan itu serta membuat perkiraan biaya guna melaksanakan tugas tersebut. Biaya yang diusulkan tersebut merupakan anggaran promosi yang diusulkan.

Tahap kelima adalah menentukan bauran promosi yang akan digunakan. Organisasi dapat mencari berbagai cara untuk mencapai efisiensi dengan melakukan substitusialat promosi yang digunakan.Menurut Belch\&Belch (2015) bauran promosi terdiri dari advertising, personal selling, direct marketing, public relation/publicity, sales promotion, dan internet/interactive media ditambah dengan support media. Periklanan merupakan segala bentuk penyajian dan promosi ide, barang, atau jasa secara nonpersonal oleh suatu sponsor tertentu yang memerlukan pembayaran (Kotler, 2000). Periklanan dapat digunakan untuk menciptakan citra jangka panjang dan secara efisien dapat menjangkau berbagai target sasaran yang tersebar secara geografis. Tidak seperti periklanan, personal selling melibatkan kontak langsung antara komunikator dan komunikannya baik secara tatap muka langsung maupun 
melalui bentuk-bentuk komunikasi lain. Interaksi ini memberikan suatu kegiatan komunikasi yang fleksibel, yaitu komunikator dapat melihat dan mendengar reaksi dari komunikannya secara langsung dan dapat mengubah pesan yang disampaikannya sesuai dengan kebutuhan spesifik komunikan atau sesuai dengan situasi yang terjadi.Selain personal selling, organisasi dapat berkomunikasi langsung dengan target sasarannya melalui direct marketing atau pemasaran langsung untuk menghasilkan respon atau transaksi.

Beberapa alat utama direct marketing yang dapat digunakan seperti telemarketing, direct mail, dan manajemen database. Direct marketing mempunyai beberapa sifat, yaitu nonpublic, dapat disesuaikan, terbaru (pesan dapat disampaikan dengan cepat), dan interaktif. Setiap media yang digunakan dalam direct marketing mempunyai fungsi tertentu. Selain itu, public relations atau publisitas juga mengacu pada komunikasi nonpersonal mengenai sebuah organisasi, produk, layanan, atau ide yang tidak dibayar langsung atau dilakukan dalam bentuk sponsorship. Umumnya, publisitas berbentuk berita, editorial, atau pengumunan tentang suatu organisasi, produk, atau layanan yang dibuatnya. Berbeda dengan publisitas, public relations memiliki tujuan yang lebih luas dari publisitas, yaitu membangun dan mempertahankan citra positif organisasi di mata publik yang menjadi target sasarannya.

Public relations juga menggunakan publisitas dalam aktivitasnya dan berbagai alat lainnya, seperti publikasi khusus, partisipasi dalam kegiatan masyarakat, sponsor acara khusus, dan berbagai kegiatan publik untuk meningkatkan citra organisasi. Public relations dan publisitas mempunyai daya tarik khusus karena sifatnya yang mempunyai kredibilitas tinggi, kemampuan menangkap target sasaran yang sebelumnya tidak dibidik, dan adanya dramatisasi. Bauran promosi yang lainnya adalah sales promotion yang didefinisikan sebagai kegiatan pemasaran yang memberikan nilai ekstra atau insentif kepada tenaga penjualan, distributor, atau konsumen akhir yang dapat merangsang penjualan langsung. Organisasi menggunakan alat promosi penjualan ini untuk dapat menciptakan respon yang lebih kuat dan lebih cepat. Jenis bauran pemasaran lainnya adalah media interaktif yang saat ini memungkinkan aliran informasi secara timbal balik dan pengguna dapat memodifikasi bentuk dan isi informasi secara real time. Media interaktif yang memilik dampak terbesar pada kegiatan promosi dan pemasaran adalah internet, terutama melalui komponen world wide web (website).

Berbagai bentuk promosi dalam internet bisa dilakukan, seperti periklanan dalam internet yang dapat berwujud dalam bentuk banners, sponsorship, pop-ups/pop-under, interstitial, push technology atau teknologi webcasting, dan links. Selain itu, kegiatan bauran promosi lain sepeti sales promotion, personal selling dan public relations juga bisa dilakukan melalui internet. Penggunaan internet yang sedang marak saat ini adalah penggunaan social networking atau jejaring sosial. Dalam situs jejaring sosial, pengguna dapat berbagi ide, kegiatan, acara, dan kesulitan dalam lingkup jaringan mereka. Penggunaan situs jejaring sosial atau biasa disebut media sosial menarik para komunikator untuk dapat melakukan program promosi di sana. Selain karena biaya yang relatif lebih murah, tingkat keterlibatan anggota menjadi faktor penting dalam promosi yang dilakukan, terutama pengguna dalam jaringan media sosial akan lebih mudah menyebarkan informasi yang penting bagi mereka. Contoh dari situs jejaring sosial adalah facebook, myspace, twitter, Instagram, linkedin dan lain sebagainya.

Salah satu bauran promosi yang paling lama, tetapi masih efektif digunakan adalah printed material. Pilihan material tercetak yang biasa digunakan adalah brosur, newsletter, booklet, flyer, kalender, bumper sticker, dan katalog yang memberi ruang dan kesempatan 
yang lebih untuk menyajikan informasi yang lebih rinci mengenai produk ataupun layanan yang dipromosikan. Terkadang, para target sasaran bahkan sangat bergantung pada material ini karena mereka dapat membawanya pulang untuk melihat dengan lebih seksama atau bahkan dapat membaginya kepada yang lain. Bauran promosi lain yang sering digunakan juga adalah support media dalam bentuk promotional product marketing atau barang promosi khusus. Barang promosi khusus merupakan kategori promosi yang unik dan dapat menjadi pengingat. Barang-barang ini dapat membantu promosi dan pesan program. Jika didesain dengan lebih strategis, fungsional, dan berkelanjutan, barang-barang ini dapat menjadi pengingat akan suatu produk atau merek. Ada lebih dari 15.000 item iklan khusus seperti ballpoint, mug kopi, gantungan kunci, kalender, $t$-shirt, dan lain sebagainya.

Tahap ketujuh adalah tahap evaluasi atau mengukur hasil promosi yang telah dilakukan. Berbagai metode dapat digunakan untuk mengukur hasil promosi, seperti intercept survey, focus group discussion, theater test, dan tracking studies. Dalam hal ini, komunikator harus dapat mengumpulkan ukuran perilaku dari tanggapan para target sasaran, seperti tingkat kesukaan sampai intensitas penggunaan atau pembelian. Tahap kedelapan adalah bagaimana komunikator dapat mengelola dan mengoordinasikan komunikasi pemasaran terpadu. Dalam hal ini, komunikasi pemasaran terpadu merupakan suatu konsep perencanaan komunikasi pemasaran yang memikirkan nilai tambah dari suatu rencana komprehensif yang mengevaluasi peran strategis berbagai disiplin komunikasi. Komunikasi pemasaran terpadu dapat memperbaiki organisasi dalam menjangkau target sasaran yang tepat, pada saat yang tepat, dan di tempat yang tepat.

\section{METODE}

Penelitian ini menggunakan studi evaluatif karena bertujuan mengevaluasi implementasi strategi komunikasi promosi dan pemasaran yang dilakukan agar informasi hasil penelitian yang ada di PDII dapat diakses dan digunakan oleh masyarakat luas. Desain penelitian menggunakan desain penelitian studi kasus dengan single level analysis dengan permasalahan tunggal, yaitu bagaimana implementasi strategi komunikasi promosi dan pemasaran yang dilakukan.

Pengumpulan data dilakukan dengan wawancara mendalam, observasi, dan studi dokumen. Wawancara mendalam dilakukan terhadap empat informan kunci, yaitu Kepala PDII, Kepala Bidang Diseminasi Informasi, Kepala bidang Sarana Akses Informasi, dan Pejabat Pranata Humas. Pemilihan informan dilakukan menggunakan metode purposive sampling. Peneliti menentukan kriteria yang sangat spesifik dan sesuai dengan kriteria yang telah ditetapkan sebelumnya, yaitu informan merupakan pihak internal lembaga yang mempunyai peran langsung dalam pembuatan keputusan dan kebijakan saat menentukan strategi komunikasi promosi dan pemasaran, serta informan yang merupakan pihak internal lembaga yang bersentuhan langsung dengan kegiatan promosi dan pemasaran. Peneliti hanya mengambil informan dari kalangan internal karena ingin mengevaluasi dari sisi internal lembaga sehingga tidak melibatkan pihak eksternal dalam penelitian ini. Teknik analisis data yang digunakan adalah coding dengan tiga tahapan, yaitu open coding, axial coding, dan selective coding. Lokasi dan objek penelitian adalah PDII yang berada di Jakarta. 


\subsection{HASIL DAN PEMBAHASAN}

\subsection{Produk dan Layanan}

Produk dan layanan informasi hasil penelitian yang dibuat oleh PDII ditujukan untuk berbagai lapisan masyarakat, seperti Indonesian Scientific Journal Database (ISJD) dan Library Archive System (LARAS) yang ditujukan bagi dosen dan mahasiswa. Untuk para pengambil kebijakan, PDII mempunyai produk yang diberi nama analisis informasi bidang yang terdiri dari 16 bidang keilmuan, antara lain energi, pangan, hukum, teknologi, sosial, dan lain-lain. Untuk mengetahui tren penelitian, PDII mempunyai produk yang diberi nama Tracking hasil penelitian. Untuk industri, ada produk yang bernama pohon industri, dan untuk UKM ada panduan usaha.

\subsection{Penentuan Target Sasaran}

Untuk menentukan segmen, PDII telah berupaya untuk mengelompokkan target sasarannya ke dalam beberapa kelompok, seperti peneliti, akademisi, pengambil kebijakan, dll.Pengelompokan ini didasarkan pada demografis dan perilaku. Demografis dilihat dari sisi pekerjaan dan pendidikan, sedangkan perilaku dilihat dari sisi pengetahuan, sikap, dan tanggapan. Untuk unsur demografis, karena target awalnya adalah komunitas ilmiah seperti perguruan tinggi, target yang dituju adalah orang dengan tingkat pendidikan di atas sekolah menengah dan berprofesi sebagai dosen, peneliti, atau mahasiswa. Proses segmentasi yang dilakukan pun dimulai dengan survei kebutuhan pengguna sehingga dapat diketahui apa saja yang dibutuhkan oleh target sasaran dan apa yang bisa dipenuhi. PDII kemudian mengidentifikasi target sasarannya dengan melihat karakter dan potensi yang dimiliki oleh target serta peluang yang dapat dipenuhi. Untuk target perguruan tinggi, misalnya, PDII melihat perguruan tinggi mana yang termasuk kategori perguruan tinggi yang besar, tetapi belum mempunyai sumber daya informasi ilmiah yang mencukupi kebutuhan para civitas academica-nya kemudian membuat profiling target sasaran.

Profiling dilakukan dengan melihat website resmi para target sasaran dan data dari hasil survei yang dilakukan. Walaupun survei yang dilakukan adalah survei kebutuhan untuk menentukan produk yang akan dibuat, namun hal ini merupakan upaya penting yang dilakukan untuk penentuan target sasaran. Dilihat dari pola segmentasi pasar, preferensi yang muncul adalah preferensi terkelompok, yaitu suatu kondisi pasar yang telah menunjukkan kelompok preferensi yang berbeda atau pasar sudah tersegmen secara alami karena komunitas ilmiah pastinya adalah orang yang terbentuk secara alami ada dalam lingkup kegiatan ilmiah. PDII kemudian memilah dari komunitas ilmiah ini maka yang akan disasar secara lebih spesifik. Selain itu, PDII menentukan target sasarannya berdasarkan statistik pengguna layanannya. Terlihat dari statistik tersebut terlihat bahwa pengguna layanan PDII paling banyak adalah kalangan mahasiswa. Hal ini menjadi acuan bagaimana PDII dapat mempromosikan produk dan layanannya bagi para mahasiswa sebagai pengguna terbesar layanan PDII. 
Tabel 1. Pengguna Layanan PDII

\begin{tabular}{|l|c|c|c|c|}
\hline \multicolumn{1}{|c|}{ Pengguna } & 2014 & 2015 & 2016 & $\begin{array}{c}2017 \\
\text { (Maret) }\end{array}$ \\
\hline Karyawan & 355 & 270 & 268 & 38 \\
\hline Karyawan LIPI & 20 & 12 & 13 & 1 \\
\hline Mahasiswa S1 & 3.230 & 2.399 & 3.487 & 751 \\
\hline Mahasiswa S2 & 280 & 227 & 43 & 22 \\
\hline Mahasiswa S3 & 42 & 36 & 16 & 8 \\
\hline Pelajar & & 210 & 100 & 45 \\
\hline Peneliti & 795 & 923 & 514 & 13 \\
\hline Peneliti LIPI & 122 & 67 & 56 & 3 \\
\hline Wiraswasta & 94 & 115 & 166 & 3 \\
\hline Industri & 0 & 11 & 5 & 0 \\
\hline Umum & 0 & 11 & 226 & 24 \\
\hline
\end{tabular}

Untuk penentuan target sasaran, PDII belum memenuhi langkah-langkah penentuan sasaran sesuai pendapat Belch \& Belch (2015). Walaupun dilakukan survei kebutuhan, akan lebih baik apabila PDII melakukan STP sesuai dengan prosedur yang dinyatakan oleh Belch \& Belch sehingga hasil dari STP ini akan membuat target audiens PDII lebih jelas, mengerucut, dan presisi sesuai dengan target sasaran dari tiap produk yang dibuat. Dengan demikian, komunikasi promosi yang dilakukan pun dapat disesuaikan dengan target sasaran. STP dapat dilakukan dengan melihat pada unsur geografis, demografis, psikografis, dan perilaku. Dengan melihat hal ini, media atau pesan yang disampaikan dapat disesuaikan.

Untuk penentuan positioning, PDII belum melakukannya. Harapan PDII adalah menjadi rujukan utama dalam penyediaan informasi ilmiah. Namun, keinginan tersebut belum dituangkan ke dalam positioning statement produk ataupun layanan sehingga tidak terlihat citra apa yang memang diinginkan oleh PDII melalui produknya tersebut. PDII saat ini sedang berupaya untuk melakukan branding organisasinya, namun upaya ini masih belum optimal dan masih dalam tahap persiapan. Untuk dapat menentukan positioning-nya, PDII dapat melihat dari kategori positioning dalam komunikasi pemasaran sosial. Dalam hal ini, PDII dapat membuat positioning yang berfokus pada manfaat ataupun positioning yang berfokus pada hambatan, yaitu sebagai solution problem bagi para penggunanya.

\subsection{Tujuan Komunikasi}

Ketika melakukan program promosi, tujuan yang ingin dicapai adalah mengenalkan dan memberikan pemahaman kepada masyarakat bahwa PDII mempunyai sumber daya informasi ilmiah untuk kemajuan riset di Indonesia dan mengenalkan brand PDII kepada masyarakat sesuai dengan pernyataan informan 1 "memperkenalkan brand ini kepada masyarakat, jadi memang promosi dengan memperkenalkan brand kepada masyarakat itu", "promosi produk kita dikenal, tujuan kita tercapai". Jika dilihat dari tujuan di atas, apabila dianalisis dengan empat tujuan komunikasi dari Rossiter \& Percy dalam Kotler \& Keller (2012), tujuan tersebut masuk ke dalam kategori menciptakan kesadaran akan merek (brand awareness) karena PDII berusaha untuk membuat masyarakat familier dengan brand PDII beserta produk dan layanan yang dibuat juga memberikan informasi kepada masyarakat mengenai ciri khusus dan manfaat produk yang dihasilkannya. 


\subsection{Perancangan Pesan}

Setiap kegiatan promosi yang dilakukan, pesan yang disampaikan dirancang terlebih dahulu. Umumnya, humas yang menyiapkan rancangan pesan. Namun pesan yang dirancang hanya untuk kegiatan promosi yang dianggap besar, seperti iklan di radio, printed material, wall banner, kelengkapan pameran, konferensi pers, dan workshop atau FGD. Isi pesan yang ditampilkan pada saat promosi biasanya lebih pada menunjukkan manfaat dari produk yang dibuat dan bagaimana masyarakat dapat mengakses produk atau layanan yang dibuat.
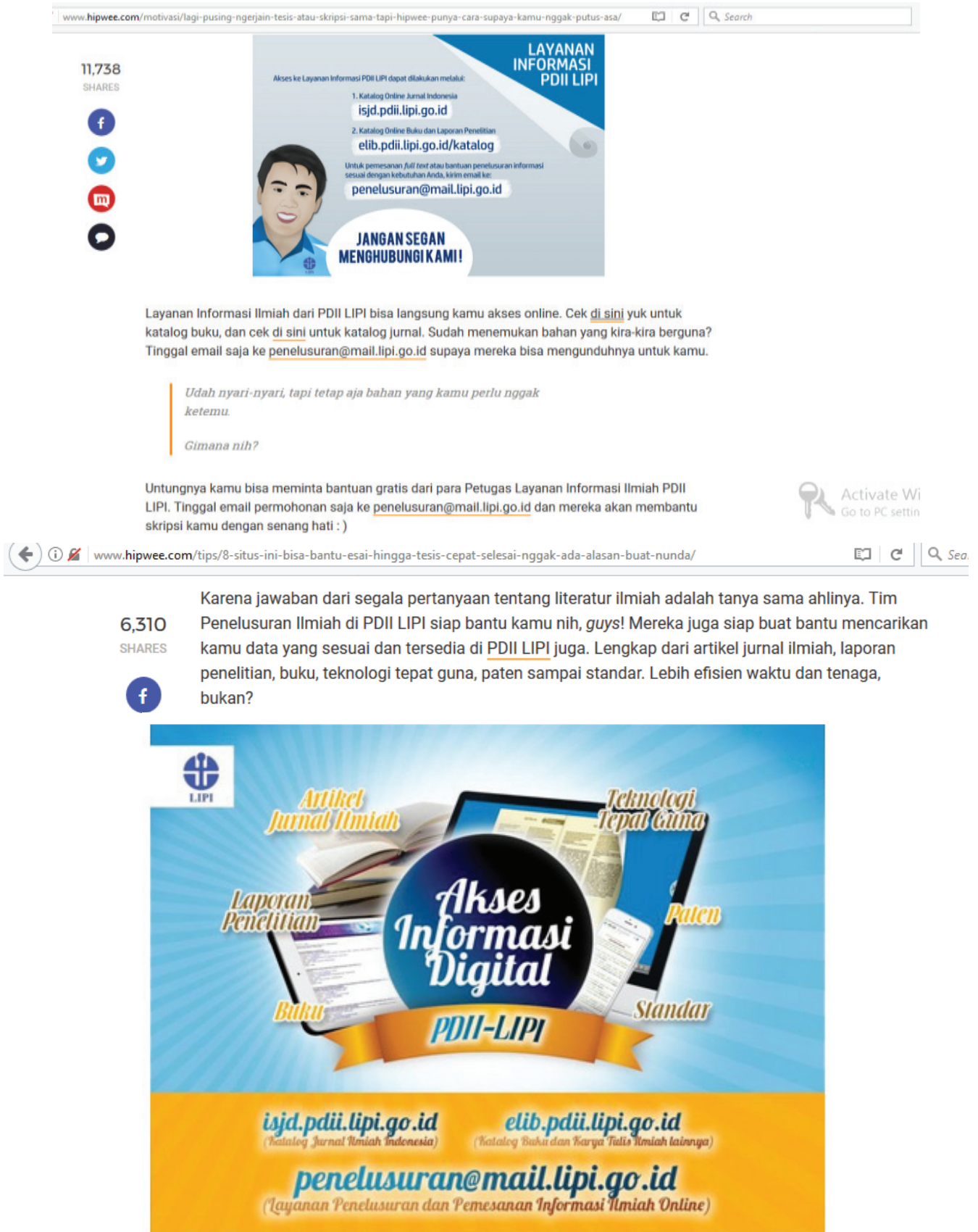

Gambar 1. Contoh pesan promosi

Isi pesan seperti yang terlihat pada gambar 1, jika dilihat dari jenis daya tarik menunjukkan pada daya tarik rasional, pengguna digiring pada rasionalitas bahwa produknya sangat bermanfaat. Misalnya, terlihat pada kata-kata mereka juga bisa bantu kamu mencarikan data 
yang sesuai dan tersedia, lebih efisien waktu dan tenaga bukan? Dilihat dari struktur pesan, maka pesan termasuk pada kategori penyajian satu sisi, yaitu pesan yang hanya menyampaikan keunggulan-keunggulan dari produk. Jika dilihat pada kata-kata udah nyarinyari tapi tetap bahan yang kamu cari belum ketemu? untungnya kamu bisa minta bantuan gratis ke petugas layanan informasi PDII, tinggal email permohonan kamu saja ke penelusuran@mail.lipi.go.id dan mereka akan bantu kamu dengan senang hati. Untuk sumber pesan, PDII tidak menggunakan orang terkenal untuk menyampaikan pesan-pesannya, karyawan PDII sendiri yang berperan sebagai penyampai pesan. Walaupun tidak menggunakan orang terkenal, PDII berusaha menampilkan sisi expertise dari penyampai pesan bahwa karyawan PDII merupakan orang yang ahli di bidang informasi ilmiah.

Untuk perancangan isi pesan ini, PDII sudah cukup terlihat berupaya untuk menampilkan pesan yang menonjolkan kelebihan dan manfaat produknya serta disesuaikan dengan format pesan yang efektif. Walaupun tidak menggunakan sumber pesan orang terkenal untuk menarik pengguna, PDII tetap memberikan pelatihan mengenai produk knowledge kepada para karyawannya agar ketika menyampaikan pesan promosi, karyawan sudah sangat paham akan produk dan layanan PDII secara rinci dan menampilkan sosok keahlian nya.

\subsection{Penganggaran}

Untuk anggaran pembiayaan promosi, pada dasarnya setiap tahun PDII selalu menganggarkan. Hanya saja, nominalnya tidak tetap dan apabila ada pemotongan anggaran, sering kali program promosi termasuk yang dipotong, tetapi tidak samai nol, masih disediakan anggaran untuk kegiatan promosi. Penganggaran biaya untuk promosi terbantu dari adanya kegiatan dari Pendapatan Negara Bukan Pajak (PNBP). PNBP ini digunakan minimal untuk printed material, souvenir, dan perjalanan dinas untuk pameran. Untuk kegiatan promosi lain, sifatnya tentatif sesuai dengan anggaran yang tersedia.

Mengacu pada metode penganggaran biaya dari Kotler (2000), metode penganggaran yang dilakukan oleh PDII adalah metode sesuai kemampuan (affordable method).Hal ini menyebabkan perencanaan komunikasi untuk jangka panjang menjadi sulit untuk dilakukan. Penganggaran promosi seharusnya dilakukan dengan cara tujuan dan tugas (objective and task method) sehingga dapat dilakukan perencanaan promosi dengan tujuan jangka panjang dan jangka pendek. Selain itu, kegiatannya dapat lebih terencana dan tersruktur dengan baik karena tugas-tugas yang dilakukan dalam kegiatan promosi dapat dilakukan sesuai dengan tujuan yang ingin dicapai.

\subsection{Saluran komunikasi}

PDII menerapkan dua saluran, yaitu saluran personal dan nonpersonal dalam komunikasi promosi yang dilakukannya. Saluran komunikasi personal yang dilakukan seperti melalui telepon, surat elektronik (e-mail), WhatsApp, kunjungan antar-lembaga, dan FGD. Saluran komunikasi nonpersonal yang dilakukan seperti iklan di radio, penggunaan website, pameran, poster, banner, brosur, konferensi pers, dan open house. PDII lebih sering menggunakan saluran komunikasi personal karena dianggap lebih privat dan lebih dapat mengetahui keinginan dan kebutuhan pengguna. Namun, saluran nonpersonal pun bisa menjadi pintu masuk untuk suatu keberhasilan komunikasi promosi karena dari saluran nonpersonal itulah awal mula pengguna tahu mengenai produk dan layanan PDII kemudian berlanjut ke saluran personal untuk mengetahui lebih banyak dan mulai menggunakan produk atau layanan. Apabila dilihat dari uraian di atas, PDII sudah melakukan penentuan saluran 
komunikasi dengan proporsional. Saluran komunikasi dipilih berdasarkan tujuan komunikasi dan kebutuhan. Pada poin ini, apa yang dilakukan oleh PDII sudah sesuai dengan teori saluran komunikasi.

\subsection{Bauran Promosi}

Bauran promosi jenis periklanan yang dilakukan oleh PDII adalah iklan di radio Sonora berupa jingle iklan yang tayang tiga kali dalam sehari selama satu bulan. Apabila dianalisis menggunakan 5M dari Kotler, dapat dijabarkan bahwa dari sisi tujuan (mission), penggunaan iklan di radio lebih pada untuk mengenalkan produk dan layanan PDII (brand awareness). Anggaran (money) yang digunakan untuk beriklan di radio sebesar $\mathrm{Rp}$ 50.000.000,- kemudian pesan (message) yang disampaikan adalah memberikan pemahaman kepada masyarakat dalam hal ini adalah para pencari referensi ilmiah bahwa PDII mempunyai koleksi literatur ilmiah yang dapat dimanfaatkan oleh masyarakat. Media yang digunakan dalam hal ini adalah radio. Pemilihan Radio Sonora sebagai media promosi karena melihat jangkauan radio yang cukup besar dan segmen yang ditarget adalah para mahasiswa atau anak muda, ditambah lagi dengan penyesuaian anggaran yang bisa masuk untuk beriklan di Sonora. Yang terakhir adalah pengukuran (measurement). Sayangnya, pengukuran iklan yang tayang ini belum dilakukan oleh PDII sehingga efektivitas dari iklan di radio ini belum dapat diketahui.

Untuk personal selling, karyawan mempromosikan PDII ketika mereka berkesempatan menjadi narasumber suatu kegiatan di luar PDII. Pameran sebagai fungsi sales promotion juga kerap dilakukan oleh PDII. Tercatat selama tahun 2016 PDII mengikuti kegiatan pameran lebih dari 10 kali, di antaranya Pameran Pekan Inovasi Teknologi, Pameran Harteknas, dan Pameran HUT Perpusnas. PDII juga sering menerima kunjungan dari instansi lain, terutama perguruan tinggi, seperti FIB UI, Universitas Yarsi, Universitas Diponegoro, dan Perpustakaan Nasional. Untuk promosi dalam bentuk publisitas/public relations, PDII kerap melakukan konferensi pers minimal dua kali dalam satu tahun untuk event rutin Lokakarya Nasional Dokinfo serta Memory of the World. Open house pun pernah dilakukan oleh PDII di hari ulang tahunnya yang ke-50 untuk mempromosikan produk dan layanannya.

Untuk kegiatan direct marketing, PDII melakukan suatu kegiatan yang diberi nama PDII Goes to Campus. Kegiatan ini dilakukan secara door to door ke perguruan tinggi yang dijadikan target sasaran oleh PDII, seperti Universitas Yarsi, Universitas Tarumanegara, Universitas Atmajaya, dan Universitas Trisakti.

Untuk promosi menggunakan internet/interactive marketing, PDII mempunyai website sebagai pintu masuk semua informasi mengenai PDII. Sayangnya pengembangan website saat ini kurang mendapat perhatian karena terbatasnya SDM yang mengelola. Selain itu, PDII cukup aktif di media social seperti Facebook (PDII), Twitter (@PDII_LIPI) dan Youtube (redaksi PDII). Pada tahun 2016, PDII juga menggunakan media sosial Hipwee untuk melakukan promosi produk dan layanannya. Promosi di media sosial ini cukup mendapat respon yang baik dari masyarakat. Setelah berpromosi di Hipwee, permintaan untuk layanan informasi mengalir cukup deras ke PDII setelah informasi tentang PDII tayang di Hipwee dan mendapat share artikel sebanyak 11.000-an share. Untuk mengelola akun media sosial tersebut, PDII menempatkan satu orang yang disebut dengan PPID untuk dapat mengelola media sosial tersebut. Untuk beriklan di internet seperti menggunakan banner, link, interstitial maupun pop up/popunder, PDII belum melakukannya karena adanya keterbatasan biaya untuk promosi dan masih kesulitan untuk menggunakan media tersebut. 
Selain berbagai alat promosi di atas, PDII juga masih menggunakan printed material seperti brosur, flyer, dan poster dan juga barang promosi khusus seperti pena, mug, gantungan kunci, dan kipas sebagai media pengingat bagi para penguna untuk mengenalkan PDII.

Dilihat dari uraian di atas, alat-alat promosi yang dikemukakan oleh Belch\&Belch (2015) telah banyak digunakan oleh PDII walaupun belum semuanya dan masih banyak keterbatasan. Untuk penentuan bauran promosi, terlihat PDII sudah berupaya untuk menggunakan berbagai alat promosi dalam kegiatan komunikasinya. Namun sayangnya alat promosi yang digunakan pun disesuaikan dengan kondisi anggaran. Secara keseluruhan, untuk bauran promosi ini sudah cukup bagus dan bervariasi, hanya perlu ditingkatkan pada sisi personil untuk personal selling dan pameran serta pembenahan website sebagai pintu masuk informasi mengenai PDII. Selain itu, untuk konten social media juga diusahakan ada aturan yang baku karena akun di media social tersebut sebagai akun official corporate yang harus ditentukan bahasa dan kontennya, tidak seperti akun individual yang bisa posting apapun juga.

\subsection{Pengukuran Hasil Promosi}

Evaluasi promosi yang dilakukan oleh PDII masih berupa evaluasi sederhana berupa pengamatan dan data-data kunjungan serta tercapai atau tidaknya target yang telah ditetapkan di awal tahun. Evaluasi pencapaian target dilakukan di bawah komando tim Perencanaan Monitoring dan Evaluasi (PME). Selain target, tim PME juga mengevaluasi penyerapan anggaran. Selain itu, PDII secara rutin setiap tahun melakukan Survei Kepuasan Masyarakat (SKM) untuk mengetahui seberapa besar kepuasan para pengguna terhadap layanan PDII. SKM ini rutin dilakukan karena PDII telah menerapkan ISO 9001:2008. Hasil dari SKM ini setiap tahunnya terus meningkat. Pada tahun 2015, PDII memperoleh nilai SKM sebesar 75,5 sedangkan pada tahun 2016 mendapat nilai 81, 697. Ini menunjukkan bahwa para pengguna menyatakan puas dengan produk dan layanan PDII. Namun sayangnya, PDII belum melakukan evaluasi yang komprehensif mengenai kegiatan promosi yang dilakukan sehingga belum dapat diketahui efektivitas dari berbagai alat dan media promosi yang telah digunakan. Dari data pengguna produk dan layanannya, PDII dapat melakukan evaluasi promosi tersebut bisa dimulai dari yang sederhana berupa media promosi yang memapar para pengguna sampai pada efektivitas pesan yang digunakan atau menggunakan tracking studies.

\subsection{Pengelolaan Komunikasi Pemasaran Terpadu}

Menurut American Association of Advertising Agencies dalam Kotler \&Keller (2012), komunikasi pemasaran terpadu merupakan suatu konsep perencanaan komunikasi pemasaran yang memikirkan nilai tambah dari suatu rencana komprehensif yang mengevaluasi peran strategis berbagai disiplin komunikasi, misalnya periklanan umum, tanggapan langsung, promosi penjualan, dan hubungan masyarakat, serta menggabungkan berbagai disiplin itu untuk memberikan kejelasan, konsistensi, dan pengaruh komunikasi yang maksimum melalui integrasi menyeluruh atas pesan-pesan yang berlainan.

Pengelolaan komunikasi pemasaran terpadu di PDII dimulai dari penyusunan perencanaan dan perumusan strategi promosi. Penyusunan perencanaan dilakukan secara bottom up, yakni dari para karyawan baik fungsional maupun struktural menyampaikan proposal perencanaan kegiatan promosi kepada pimpinan. Kemudian, pimpinan yang akan menyeleksi dan mengoreksi termasuk masalah penganggarannya. Untuk perumusan strategi promosi, PDII melihat beberapa faktor yang mempengaruhi, seperti faktor SDM di internal PDII, faktor koordinasi dengan BKHH di internal LIPI, dan faktor peluang-peluang yang ada 
di luar. Dengan memperhatikan beberapa faktor tersebut, strategi promosi yang dilakukan diharapkan dapat mencapai tujuan yang telah ditetapkan. Kegiatan promosi dalam Rencana Strategis Organisasi tidak muncul secara eksplisit, namun nama yang muncul dalam renstra adalah kerja sama yang masuk di kegiatan difusi dengan misi terjalinnya kerja sama luar dan dalam negeri.

Pengorganisasian kegiatan promosi di PDII diserahkan kepada pranata humas sebagai koordinatornya. Dalam kegiatan promosi ini, tugas pokok dan fungsi dari Bidang Diseminasi Informasi mengarah ke kegiatan promosi juga, tetapi subbagian Umum juga mempunyai tugas ke arah promosi. Hal ini terbukti dengan adanya penempatan pranata humas di bawah subbagian umum. Selain itu, secara struktur organisasi, kegiatan promosi tidak masuk secara eksplisit dalam struktur organisasi. Tim promosi yang melakukan kegiatan promosi, tidak dibentuk secara khusus, tetapi terbentuk secara incidental. Hal ini menyulitkan -pencapaian tujuan jangka panjang karena anggota tim akan terus berganti-ganti.

Koordinasi kegiatan promosi yang dilakukan PDII masih bersifat birokratis dan hanya berupa meeting atau pertemuan ketika akan dilakukan sebuah event. Padahal, hakikatnya koordinasi harus terus dilakukan di antara bidang-bidang yang bertanggung jawab terhadap kegiatan promosi dan tidak hanya ketika akan berlangsung sebuah kegiatan event bahkan dari sejak awal perencanaan kegiatan dilakukan.

Dari uraian di atas, dapat terlihat bahwa pengelolaan dan pengkoordinasian komunikasi pemasaran terpadu di PDII belum berjalan dengan baik. Harus ada sinergitas antarkomponen dalam lingkup organisasi PDII sehingga kegiatan promosi dan pemilihan media ataupun kegiatan yang dilakukan dapat terintegrasi dengan baik. Dengan demikian, tujuan dari kegiatan-kegiatan promosi dapat tercapai dengan lebih baik lagi. Selain itu, PDII belum terlihat concern terhadap promosi. Perencanaan maupun pembiayaan masih seadanya. Tidak ada pula tim ataupun bagian yang khusus menangani promosi, tim hanya sebatas incidental per-kegiatan dan pranata humas yang menangani promosi pun hanya satu orang. Pemilihan media promosi juga belum banyak variasi dan PDII kurang berani untuk tampil berpromosi. Diharapkan PDII dapat merencanakan strategi komunikasi promosinya dengan baik dengan memadupadankan setiap media promosi yang digunakan agar tujuan yang diinginkan dapat tercapai dengan baik.

\section{KESIMPULAN}

Berdasarkan uraian di atas, dapat ditarik kesimpulan sebagai berikut.

1) Strategi komunikasi promosi yang sudah dilakukan oleh PDII telah memenuhi tujuh dari delapan komponen - komunikasi promosi yang efektif. Ketujuh komponen yang telah ada adalah penentuan target sasaran dengan melakukan STP, penetapan tujuan komunikasi, perancangan pesan komunikasi, penetapan saluran komunikasi, penetapan anggaran, penentuan bauran promosi, dan pengelolaan serta pengkoordinasian komunikasi pemasaran terpadu. Dari beberapa unsur tersebut, ada satu unsur yang belum dilakukan, yaitu pengukuran hasil promosi terhadap target sasaran.

2) Walaupun telah memenuhi tujuh komponen, ada beberapa komponen yang belum maksimal, seperti belum ditetapkannya positioning yang merupakan suatu hal penting, yaitu lembaga ingin dicitrakan seperti apa di benak para penggunanya. Positioning juga sebagai pembeda antara satu produk dan produk lainnya. PDII harus membuat sebuah positioning yang menjelaskan manfaat produk atau perbedaan produk layanan akses informasi yang dibuat oleh PDII dengan layanan yang dibuat oleh lainnya. 
3) Penentuan strategi komunikasi yang dilakukan oleh PDII belum efektif. Ada beberapa bagian yang harus dipertajam lagi oleh PDII agar strategi komunikasi promosinya bisa lebih efektif, yaitu dari STP yang dilakukan. Segmenting dan targeting harus bisa lebih presisi, segmen yang dibidik lebih mengerucut dan lebih spesifik lagi. Penentuan segmen harus dilihat dari faktor-faktor, seperti geografis, demografis, psikografis, dan perilaku sehingga komunikasi yang dilakukan bisa sesuai dan tepat sasaran.

4) Sistem pengganggaran masih menggunakan metode affordable methods. Anggaran untuk kegiatan komunikasi promosi ini seharusnya bisa disusun berdasarkan metode tujuan dan tugas. PDII harus menentukan tujuan spesifik dari kegiatan promosi yang dilakukan kemudian menentukan tugas-tugas atau pekerjaan apa yang harus dilakukan untuk mencapai tugas tersebut. Pembiayaan didasarkan pada tugas yang harus dilakukan sehingga tujuan jangka panjang dan pendek bisa tercapai.

5) PDII belum mempunyai tim promosi yang khusus dan fokus sehingga kegiatan komunikasi bisa lebih komprehensif dan tujuan PDII untuk lebih mengenalkan produk dan layanannya bisa tercapai.

\section{DAFTAR PUSTAKA}

Belch, George E. and Michael A. Belch. 2012. Advertising and Promotion, an Integrated Marketing Communication Perspective $9^{\text {th }}$ Edition. Singapore: Mc Graw Hill.

Broussard, Sharee leblanc. 2011. Source-Massage-Receiver in Integrated Marketing Communication. International Journal of Education Advancement, Vol 10 No 4, 139-152.

Edmiston, Dawn. 2009. An Examination of Integrated Marketing Communication in US Public Institution of Higher Education. International Journal of Education Advancement, Vol 8 No $3-4,152-175$.

Keller, Kevin Lane. 2003. Strategic Brand Management: Building, Measuring, and Managing Brand Equity. Prentice Hall.

Kotler, Philip and Alan. R. Andreasen. 1995. Strategi Pemasaran untuk Organisasi Nirlaba, Edisi Ketiga, Yogyakarta: Gadjah Mada University Press.

Kotler, Philip and Nancy Lee. 2007. Marketing in the Public Sector. New Jersey: Pearson Education.

Kotler, Philip and Nancy Lee. 2008. Social Marketing; Influencing Behaviour for Good, Third Edition. California: SAGE Publication.

Kotler, Philip. 2000. Marketing Management: The Millenium Edition. New Jersey: Prentice Hall.

Moleong, J. L. 2005. Metodologi Penelitian Kualitatif. Bandung: PT Remaja Rosda Karya.

Muntashir. 2011. Informasi Ilmiah Berbasis Open Access: Sumber dan Sarana Penelusurannya. Jurnal Palimpsest, Vol.4 No.1, pp 30-36.

Neuman, W. Lawrence. 2013. Metode Penelitian Sosial: Pendekatan Kualitatif dan Kuantitatif. Jakarta: PT Indeks. 
O'Connor, Lisa and Kacy Lundstrom. 2011. The Impact of Social Marketing Strategies on The Information Seeking Behaviours of College Student. Reference and User Service Quarterly, Vol. 50 No 4, 351-365.

Patton, Michael Quinn. 2015. Qualitative Research \& Evaluation Methods, California: SAGE Publications.

Poerwandari, Kristi. 2001. Pendekatan Kualitatif untuk Penelitian Perilaku Manusia. Jakarta: LPSP3. Fakultas Psikologi UI.

Subekti, Nanang Bagus. 2015. "Ranking Publikasi Ilmiah Internasional Indonesia". Koran Sindo Edisi 13 April 2015, Jakarta. 
